\title{
Effect of Dietary Lysine and Arginine Levels on Bone Development in Broiler Chicks
}

\author{
Tokie SEKINE, Keisuke UENO, Emiko WATANABE*, \\ Motoni KADOWAKI and Teru ISHIBASHI \\ Faculty of Agriculture, Niigata University, Niigata-shi 950-21 \\ * Department of Biotechnology, Tokyo Technical College, \\ Kunitachi-shi 186
}

(Received June 13, 1995)

\begin{abstract}
To prevent leg abnormalities of broilers by nutritional managements, the effect of dietary lysine (Lys) and arginine (Arg) levels on bone development in female chicks was investigated. Eight-day-old female broiler chicks of Cobb strain were housed individually and given experimental diets and water ad libitum for 10 days. To clarify the effect of dietary Lys level, five experimental diets were formulated to include $0.6,1.0,1.4,1.8$ and $2.2 \%$ Lys in the presence of $0.8 \% \mathrm{Arg}$, which made different ratios of Lys/Arg. In addition, a diet with $2.2 \% \mathrm{Lys}$ $+2.0 \%$ Arg was employed as a high Lys but lower Lys/Arg diet. The control diet contained $1.2 \%$ Lys and 1.4\% Arg. Better grow th performance and bone development were obtained on the 1.0 and $1.4 \%$ Lys diets with no significant difference from the control diet. However, those in the 0.6, 1.8 and $2.2 \%$ Lys diets were significantly inferior to those in the control diet. Leg abnormalities were observed in the 1.8 and $2.2 \%$ Lys diets, but not in the $0.6 \%$ Lys diet. Addition of Arg up to $2.0 \%$ to the $2.2 \%$ Lys diet alleviated the growth depression and leg abnormality caused by excess Lys. The blood $\mathrm{pH}$ of chicks on the high Lys/Arg diet was lower than that on the other diets. These results suggest that an unbalanced, high Lys/Arg diet inhibits bone development as well as growth in chicks, leading to leg abnormalities possibly caused by a decrease in blood $\mathrm{pH}$.

Anim. Sci. Technol. (Jpn.) 67 (1) : 7-13, 1996

Key words : arginine, lysine, bone development, blood $\mathrm{pH}$, broiler
\end{abstract}

Leg abnormalities of broilers have been a serious problem for poultry industry. There have been many reports showing that dietary protein affects bone development, For example, a high-protein diet reduces bone formation at the osteogenesis step in rats ${ }^{19}$, and increases urinary calcium excretion in $\operatorname{man}^{9)}$. In our previous report ${ }^{15)}$, however, the diets including well-balanced amino acids adjusted to the NRC requirements ${ }^{10)}$, even with high level of amino acids, did not inhibit bone development in broiler chicks. This indicates that the wellbalancing of amino acids in the diet may allevi- ate the negative effect of a high-protein diet on bone development. In other words, the negative effect may be caused by a specific or unbalanced amino acid(s). In fact, dietary lysine $(\text { Lys })^{7.8)}$ and sulfur amino acids such as methionine $^{4,20)}$ induce leg abnormalities of chicks. But it is not clear how bonc development in chicks is affected by these dietary amino acids.

The purpose of the present study is to elucidate the effect of amino acids themselves and their interrelationship on bone development in chicks. Lysine and arginine (Arg) were 
SEKINE, UENO, WATANABE, KADOWAKI and ISHIBASHI

chosen here, because, as mentioned above, it is known that excess Lys depresses growth performance in broilers and addition of Arg to the excess Lys diet alleviates its negative effect ${ }^{17}$, but the effects of these two amino acids on bone development and leg abnormality are not clear.

\section{Materials and Methods}

Cobb strain female chicks were placed on a commercial diet from hatching until they were put on experimental diets. At 8 days of age, chicks were divided into 7 dietary groups of 4 chicks each with equal average body weights, and housed individually in wire cages in a temperature-constant $\left(22 \pm 2^{\circ} \mathrm{C}\right)$ and light-controlled (16 h light; 4:00-20:00) room. The chicks consumed the experimental diets and water ad libitum for 10 days. The composition of the basal diet is shown in Table 1. The diets consisted mainly of corn and soybean meal, and contained $19.3 \%$ crude protein and $3,200 \mathrm{kcal} \mathrm{ME} / \mathrm{kg}$ of diet. In order to make the effect of Lys clearer, dietary Arg level was fixed to $0.8 \%$, which is $56 \%$ of the NRC requirement ${ }^{10)}$. Dietary Lys levels were provided 5 graded levels from deficient to excess, i.e., $0.6,1.0,1.4,1.8$ and $2.2 \%$. Furthermore, two diets were prepared, the one including $2.2 \%$ Lys and $2.0 \% \mathrm{Arg}$ as a $2.0 \% \mathrm{Arg}$ diet, and the other with $1.2 \%$ Lys and $1.4 \% \mathrm{Arg}$ as a control diet. The other amino acids were added not to be less than the NRC requirements ${ }^{10)}$ when they were lower than the NRC requirements ${ }^{10)}$. Calcium and available phosphorus levels were at 1.10 and $0.56 \%$, respectively, and other nutrients were added not to be less than the NRC requirements ${ }^{10}$.

At the end of feeding period, body weight, feed consumption, and incidence of leg abnormality were recorded, and the chicks were killed after anesthetizing by i. $v$. injection of 50 mg pentobarbital per chick. Tibias were taken and cleaned, and the right bone was used for determining the bone mineral density
Table 1. Composition of basal diet $(\%)$

\begin{tabular}{lr}
\hline \multicolumn{1}{c}{ Ingredients } \\
\hline Corn & 71.20 \\
Soybean meal (44\% CP) & 7.50 \\
Corn gluten meal (62\% CP) & 10.25 \\
Soybean oil & 1.57 \\
Calcium carbonate & 0.70 \\
Calcium phosphate tribasic & 2.50 \\
Vitamin-mineral premix ${ }^{1)}$ & 0.35 \\
Sodium chloride & 0.25 \\
Choline chloride & 0.09 \\
Agar & 2.08 \\
L-lysine HCl & 0.14 \\
L-methionine & 0.13 \\
L-threonine & 0.14 \\
L-isoleucine & 0.08 \\
L-tryptophan & 0.08 \\
Glycine & 0.04 \\
L-glutamic acid ${ }^{2)}$ & 2.89 \\
Total & 100.00 \\
\hline Calculated analysis & \\
ME (kcal/kg) & 3.200 \\
Crude protein (\%) & 19.30 \\
Calcium (\%) & 1.10 \\
Available phosphorus (\%) & 0.56 \\
Total phosphorus (\%) & 0.76 \\
\hline Provides per kilogram & 1.500 \\
\hline
\end{tabular}

1) Provides per kilogram of diet: vitamin A, 1,500 IU ; vitamin $D_{s}, 200 \mathrm{ICU}$; $d l-\alpha$-tocopherol acetate, $10 \mathrm{mg}$; menadione sodium bisulfite, $0.959 \mathrm{mg}$; thiamin- $\mathrm{HNO}_{3}, 1.8 \mathrm{mg}$; pyridoxine- $\mathrm{HCl}, 3 \mathrm{mg}$; riboflavin, $3.6 \mathrm{mg}$; vitamin $\mathrm{B}_{12}, 0.009 \mathrm{mg} ; \mathrm{MnSO}_{4}, 165$ $\mathrm{mg} ; \mathrm{ZnCO}_{2}, 40 \mathrm{mg} ; \mathrm{FeSO}_{4}, 218 \mathrm{mg} ; \mathrm{CuSO}_{4}, 20 \mathrm{mg}$; $\mathrm{Ca}\left(\mathrm{IO}_{3}\right)_{2}, 0.5 \mathrm{mg} ; \mathrm{MgCO}_{3}, 600 \mathrm{mg} ; \mathrm{Ca}-$ pantothenate, $10.87 \mathrm{mg}$; biotin, $0.15 \mathrm{mg}$; nicotinic acid, $26.78 \mathrm{mg}$, and folic acid, $0.55 \mathrm{mg}$.

2) Substituted by the same amount of supplemented $\mathrm{L}$-arginine and $\mathrm{L}-\mathrm{ly}$ sine $\mathrm{HCl}$.

(BMD) using a dual X-ray absorptiometry (DXA, Hologic QDR-2000/W W $^{\mathrm{TM}}$ whole body Xray bone densitometer, Hologic Inc, MA. U.S. A.). The BMD was measured as a total area and at 4 sections with equal length, i.e., the proximal end $(\mathrm{PE})$, proximal diaphysis $(\mathrm{PD})$, distal diaphysis (DD) and distal end (DE). The left tibia was used to measure the whole length and width at the long and short axes at the 
middle of the bone between PD and DD with slide calipers. Then, the bone strength against a maximum bending load was determined at the middle of the bone (the span was $25 \mathrm{~mm}$ ) using a Shimadzu autograph AG-25 TD (Shimadzu Corp., Kyoto). The bones were subsequently defatted, dried, weighed, and ashed by the procedure of Association of Official Analytical Chemists ${ }^{1}$.

About $5 \mathrm{~m} l$ of blood samples were withdrawn by cardiac puncture from chicks using heparinized syringes. Blood $\mathrm{pH}$ was determined with a $\mathrm{pH}$ meter (Personal $\mathrm{pH}$ meter, TPX-90 i, Toko Chemical Laboratories Co., Ltd, Tokyo) immediately after blood sampling.

Statistical significance was estimated by Duncan's new multiple range test using the General Linear Models procedure in SAS ${ }^{(12)}$. Differences were considered statistically significant at $\mathrm{P}<0.05$.

\section{Results}

The effects of dietary Lys and Arg levels on growth of broilers, i.e., body weight gain, feed consumption and feed efficiency are presented in Table 2. There were no significant differences in body weight gain among 1.0 and $1.4 \%$ Lys, and the control diets. However, the body weight gain of chicks on $0.6,1.8$ and $2.2 \%$ Lys diets was significantly lower than that of chicks on the control diet. That on the $2.0 \%$ Arg diet was similar to the control diet. The effects of dietary Lys and Arg levels on feed consumption and feed efficiency had the similar tendency as those on body weight gain. As for the appearance, high incidence of leg abnormalities was observed on 1.8 and $2.2 \%$ Lys diets, but not in other dietary treatments.

The effects of dietary Lys and Arg on bone development of broiler chicks are shown in Tables 3, 4 and Fig. 1. In Table 3, the length, width, dry weight and ash weight and percentage of tibia are presented. Bone development variables except ash percentage showed the similar tendency as growth variables. However, ash percentage was not significantly affected by dietary treatments.

Tibia strength, a most critical variable for bone development, is presented in Fig. 1. Though tibia strength showed the similar tend-

Table 2. Effects of dietary lysine and arginine levels on growth of female broiler chicks from 8 to 18 days of age

\begin{tabular}{cccccc}
\hline $\begin{array}{c}\text { Lysine } \\
(\%)\end{array}$ & $\begin{array}{c}\text { Arginine } \\
(\%)\end{array}$ & $\begin{array}{c}\text { Body weight } \\
\text { gain } \\
(\mathrm{g} / 10 \text { days })\end{array}$ & $\begin{array}{c}\text { Feed } \\
\text { consumption } \\
\text { (g/10 days) }\end{array}$ & $\begin{array}{c}\text { Feed } \\
\text { efficiency } \\
\text { (Gain/Feed) }\end{array}$ & $\begin{array}{c}\text { Leg } \\
\text { abnor- } \\
\text { mality }\end{array}$ \\
\hline 1.20 & 1.40 & $313.1^{\mathrm{a}}$ & $51.8 .6^{\mathrm{a}}$ & $0.60^{\mathrm{ab}}$ & $0 / 4$ \\
0.60 & 0.80 & $177.3^{\mathrm{b}}$ & $394.8^{\mathrm{b}}$ & $0.45^{\mathrm{c}}$ & $0 / 4$ \\
1.00 & 0.80 & $301.0^{\mathrm{a}}$ & $505.9^{\mathrm{a}}$ & $0.59^{\mathrm{b}}$ & $0 / 4$ \\
1.40 & 0.80 & $293.7^{\mathrm{a}}$ & $534.4^{\mathrm{a}}$ & $0.55^{\mathrm{b}}$ & $0 / 4$ \\
1.80 & 0.80 & $192.2^{\mathrm{b}}$ & $439.1^{\mathrm{b}}$ & $0.43^{\mathrm{c}}$ & $4 / 4$ \\
2.20 & 0.80 & $184.7^{\mathrm{b}}$ & $425.8^{\mathrm{b}}$ & $0.43^{\mathrm{c}}$ & $4 / 4$ \\
2.20 & 2.00 & $324.7^{\mathrm{a}}$ & $505.6^{\mathrm{a}}$ & $0.64^{\mathrm{a}}$ & $0 / 4$ \\
& & & & \\
Pooled SE & 12.1 & 10.1 & 0.02 & \\
\hline
\end{tabular}

${ }^{a-c}$ Means within each column with no common superscript differ significantly ( $\mathrm{P}$ $<0.05)$.

Values of individual groups are means for 4 chicks.

* Leg abnormality was judged visually by typical behaviors, e.g., ataxic gait, curled feathers. 
SEKINE, UENO, WATANABE, KADOWAKI and ISHIBASHI

Table 3. Effects of dietary lysine and arginine levels on length, long axis width, short axis width, dry weight, ash weight, and ash percentage of tibia of female broiler chicks from 8 to 18 days of age

\begin{tabular}{cccccccc}
\hline \hline $\begin{array}{c}\text { Lysine } \\
(\%)\end{array}$ & $\begin{array}{c}\text { Arginine } \\
(\%)\end{array}$ & $\begin{array}{c}\text { Length } \\
(\mathrm{cm})\end{array}$ & $\begin{array}{c}\text { Long } \\
\text { axis }\end{array}$ & $\begin{array}{c}\text { Short } \\
\text { axis }\end{array}$ & $\begin{array}{c}\text { Dry weight } \\
(\mathrm{g})\end{array}$ & $\begin{array}{c}\text { Ash } \\
(\mathrm{g})\end{array}$ & $\begin{array}{c}\text { Ash } \\
(\%)\end{array}$ \\
\hline 1.20 & 1.40 & $6.20^{\mathrm{a}}$ & $0.45^{\mathrm{b}}$ & $0.43^{\mathrm{bc}}$ & $1.114^{\mathrm{b}}$ & $0.441^{\mathrm{b}}$ & 39.70 \\
0.60 & 0.80 & $5.88^{\mathrm{b}}$ & $0.40^{\mathrm{c}}$ & $0.41^{\mathrm{cd}}$ & $0.885^{\mathrm{c}}$ & $0.357^{\mathrm{c}}$ & 39.95 \\
1.00 & 0.80 & $6.27^{\mathrm{a}}$ & $0.50^{\mathrm{a}}$ & $0.46^{\mathrm{ab}}$ & $1.238^{\mathrm{ab}}$ & $0.517^{\mathrm{a}}$ & 41.64 \\
1.40 & 0.80 & $6.24^{\mathrm{a}}$ & $0.45^{\mathrm{b}}$ & $0.43^{\mathrm{bc}}$ & $1.219^{\mathrm{ab}}$ & $0.519^{\mathrm{a}}$ & 42.63 \\
1.80 & 0.80 & $5.76^{\mathrm{b}}$ & $0.39^{\mathrm{c}}$ & $0.37^{\mathrm{d}}$ & $0.88^{\mathrm{c}}$ & $0.370^{\mathrm{c}}$ & 42.54 \\
2.20 & 0.80 & $5.69^{\mathrm{b}}$ & $0.38^{\mathrm{c}}$ & $0.36^{\mathrm{d}}$ & $0.866^{\mathrm{c}}$ & $0.363^{\mathrm{c}}$ & 41.94 \\
2.20 & 2.00 & $6.35^{\mathrm{a}}$ & $0.52^{\mathrm{a}}$ & $0.49^{\mathrm{a}}$ & $1.302^{\mathrm{a}}$ & $0.548^{\mathrm{a}}$ & 42.04 \\
\end{tabular}

a-d Means within each column with no common superscript differ significantly $(\mathrm{P}<0.05)$.

Values of individual groups are means for 4 chicks.

Table 4. Effects of dietary lysine and arginine levels on bone mineral density (BMD) in tibia of female broiler chicks from 8 to 18 days of age

\begin{tabular}{ccccccc}
\hline Lysine & Arginine & \multicolumn{5}{c}{ BMD $\left(\mathrm{g} / \mathrm{cm}^{2}\right)$} \\
\cline { 2 - 7 } & $(\%)$ & Total & PE & PD & DD & DE \\
\hline 1.20 & 1.40 & $0.166^{\mathrm{b}}$ & $0.161^{\mathrm{ab}}$ & $0.169^{\mathrm{b}}$ & $0.206^{\mathrm{bc}}$ & $0.132^{\mathrm{bcd}}$ \\
0.60 & 0.80 & $0.153^{\mathrm{c}}$ & $0.147^{\mathrm{bc}}$ & $0.162^{\mathrm{bc}}$ & $0.189^{\mathrm{cd}}$ & $0.119^{\mathrm{d}}$ \\
1.00 & 0.80 & $0.180^{\mathrm{a}}$ & $0.160^{\mathrm{ab}}$ & $0.187^{\mathrm{a}}$ & $0.230^{\mathrm{ab}}$ & $0.147^{\mathrm{ab}}$ \\
1.40 & 0.80 & $0.182^{\mathrm{a}}$ & $0.169^{\mathrm{a}}$ & $0.178^{\mathrm{ab}}$ & $0.230^{\mathrm{ab}}$ & $0.157^{\mathrm{a}}$ \\
1.80 & 0.80 & $0.145^{\mathrm{c}}$ & $0.136^{\mathrm{c}}$ & $0.147^{\mathrm{c}}$ & $0.178^{\mathrm{d}}$ & $0.126^{\mathrm{cd}}$ \\
2.20 & 0.80 & $0.154^{\mathrm{bc}}$ & $0.153^{\mathrm{abc}}$ & $0.150^{\mathrm{c}}$ & $0.180^{\mathrm{d}}$ & $0.139^{\mathrm{bc}}$ \\
2.20 & 2.00 & $0.182^{\mathrm{a}}$ & $0.164^{\mathrm{ab}}$ & $0.187^{\mathrm{a}}$ & $0.235^{\mathrm{a}}$ & $0.146^{\mathrm{ab}}$ \\
\end{tabular}

a-d Means within each column with no common superscript differ significantly $(\mathrm{P}<0.05)$.

Values of individual groups are means for 4 chicks.

The BMD was measured as a total area and at 4 separate areas, i.e., proximal end (PE), proximal diaphysis (PD), distal diaphysis (DD) and distal end (DE).

ency as growth and bone development variables, it tended to be lower in chicks fed the 1.8 and $2.2 \%$ Lys diets compared to the $0.6 \%$ Lys diet.

As an index for bone calcification, the BMD of tibia was measured as a total area and at 4 separate locations (Table 4). The BMD of PD and DD exhibited the similar tendency as tibia strength.

Blood $\mathrm{pH}$, an index for acid-base balance, is shown in Fig. 2. Though there was no significant difference in blood $\mathrm{pH}$ between the $0.6 \%$ Lys and control diets, blood $\mathrm{pH}$ of chicks on the $1.8 \%$ Lys diet was lower than that of chicks on the control diet. On the other hand, the $\mathrm{pH}$ on the $2.2 \%$ Lys $+2.0 \%$ Arg diet was not different 


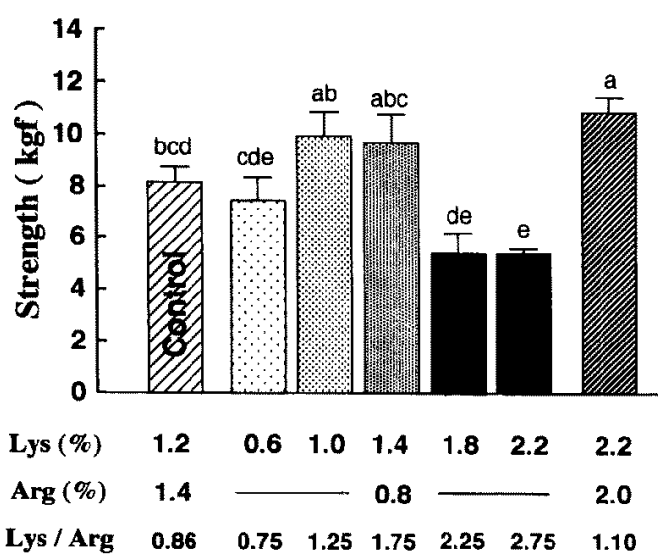

Fig. 1. Effects of dietary lysine and arginine levels on tibia strength.

Values are means $\mathrm{SE}$ for 4 chicks. Those with different letters are significantly different $(\mathrm{P}<$ $0.05)$.

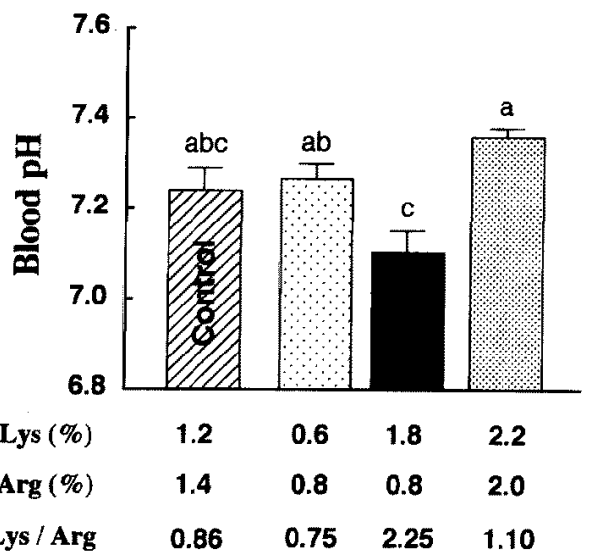

Fig. 2. Effects of dietary lysine and arginine levels on blood $\mathrm{pH}$.

Values are means $\pm \mathrm{SE}$ for 4 chicks. Those with different letters are significantly different $(\mathrm{P}<$ $0.05)$.

from that on the control diet.

\section{Discussion}

It has been known that the excessive level of dietary Lys deteriorates the growth of chicks ${ }^{6}$. This growth depression can, however, be recovered by supplementing with dietary
Arg ${ }^{17)}$. This antagonism has been explained as the excess Lys in the diet that induces kidney arginase activity resulting in the relative Arg deficiency ${ }^{2)}$. The present results not only supported these effects of Lys and Arg on growth performance but also demonstrated their effect on bone development in chicks.

The mechanism by which excess Lys exerts on bone development is not well understood. Dietary Lys supplement increases the concentration of Lys in plasma and tissues. It also decreases intracellular potassium concentration $^{7)}$, because Lys- $\alpha$-ketoglutarate reductase, a rate-limiting enzyme of Lys catabolism requiring potassium, is induced by an increase in Lys intake ${ }^{7.14)}$. Concomitantly, Lys supplementation elevates plasma chloride level ${ }^{3,5)}$ probably due to hydrochloric acid included in the crystalline amino acid. Thus, an alteration in these mineral balance must induce a reduction in blood $\mathrm{pH}$, an acidotic condition $^{5)}$. It is also reported that metabolic acidosis reduces a production of $1,25-\mathrm{di}$ hydroxycholecalciferol, which is essential for intestinal calcium absorption and for its renal reabsorption, although reported only in vitamin $\mathrm{D}$ deficient condition ${ }^{13}$. All these findings enable us to speculate that leg abnormalities in chicks fed excessive Lys may be due to an impairment in calcium availability resulting from metabolic acidosis and calcium loss in the digestive tract and kidney ${ }^{11}$.

The present results that the detrimental effect of excess Lys on bone development was overcome by increasing dietary Arg level clearly indicates that this negative effect is not caused by an absolute amount of Lys but by the unbalanced Lys/Arg ratio in the diet. Thus, the Lys-Arg antagonism exists not only in growth performance but also in bone development. This brings the following hy pothesis : the supplemented Arg to excess Lys diet may decrease Lys - $\alpha$-ketoglutarate reductase activity ${ }^{18)}$ leading to a suppression of elevated plasma Lys concentration ${ }^{17}$, restore the bal- 


\section{SEKINE, UENO, WATANABE, KADOWAKI and ISHIBASHI}

ance of electrolytes, and reduce urinary calcium excretion. However, for clarifying the details of its mechanism, more studies have to be done.

Not only normal growth but also normal bone development were obtained in the range of the Lys/Arg ratio from 0.86 to 1.75 . The detrimental effects were observed above and bclow this range, but leg abnormalities were induced only by the diets with higher ratios, but not by the ones with lower ratios. In other words, relative Lys excess or Arg deficiency caused greater damages to bone development than simple Lys deficiency ( $0.6 \%$ Lys diet). Since the blood $\mathrm{pH}$ of chicks fed on the Lys excess diet was lower than that on the Lys deficient diet, a decrease in calcium availability caused by acidosis in the Lys excess diet may have induced leg abnormalities.

From the present study, the unbalance of dietary amino acids, Lys and Arg, delayed the growth and bone development in chicks. Shafey et al. showed that the unbalance of dietary calcium and phosphorus also induced a decrease in body weight gain and an impairment of bone development, in which bone ash percentage was altered by dietary calcium/ phosphorus ratio ${ }^{16)}$. This implies that the calcium/phosphorus ratio affects bone calcification. On the contrary, the unbalanced Lys/ Arg diet in the present study decreased bone and ash weights to the same extent, resulting in no change of ash percentage. Thus, the effects on bone development are different among nutrients. As reported in our previous study, dietary amino acids are involved in overall bone growth including bone calcification and matrix formation, because ash percentage cannot be altered at all by changes in the level and balance of dietary amino acids ${ }^{15}$.

In conclusion, the present results demonstrate that the detrimental effect of dietary Lys excess on bone development is not due to the amount of Lys itself, but due to the unbalance of Lys and Arg in the diet. Therefore, the negative effect of feeding a high protein diet on bone development could be alleviated by adjusting the balance of these amino acids in the diet.

\section{References}

1) Association of Official Analytical Chemists, Official Methods of Analysis. 14th ed. Assoc. Off. Anal. Chem., Washington, DC. 1980.

2) Austic RE, Nesheim MC. Role of kidney arginase in variations of the arginine requirement of chicks. J. Nutr., $100: 855-868.1970$.

3) Calvert CC, Austic RE. Lysine-chloride interactions in the growing chick. Poultry Sci., 60 : 1468-1472. 1981

4) Gonzalez NJ, Sullivan TW, Douglas JH, Beck MM. Effect of inorganic sulfate and sulfur amino acids on bone mineralization in broilers. Poultry Sci., 72 : 1935-1943. 1993.

5) Johnson RJ, Karunajeewa H. The effects of dietary minerals and electrolytes on the growth and physiology of the young chick. J. Nutr. 115: 1680-1690. 1985.

6) Jones JD. Lysine-arginine antagonism in the chick. J. Nutr., 84 : 313-321. 1964.

7) Jones JD, Wolters R, Burnett PC. Lysine-arginine-electrolyte relationships in the rat. J. Nutr., 89 : 171-188. 1966.

8) Latshaw JD. Dietary lysine concentrations from deficient to excessive and the effect on broiler chicks. Br. Poult. Sci., 34 : 951-958. 1993.

9) Linkswiler HM, Zemel B, Hegsted M, Schuette SA. Protein-induced hypercalciuria. Fed. Proc., $40: 2429-2433.1981$.

10) National Research Council. Nutrient Requirements of Poultry. 8th rev. ed. National Academy Press. Washington, DC. 1984.

11) Roiz-Lopez B, Rangel-Lugo M, Austic RE. Effects of selected minerals on acid-base bal. ance and tibial dyschondroplasia in broiler chickens. Poultry Sci., $72:$ 1693-1704. 1993.

12) SAS Institute. SAS User's Guide: Statistics. Version 5 ed. SAS Inst. Inc., Cary, NC. 1985.

13) Sauveur B, Garabedian M, Felliot $C$, Mongin $P$, Balsan S. The effect of induced metabolic acidosis on vitamin $D_{3}$ metabolism in rachitic chick. Calcif. Tiss. Res., $23: 121-124.1977$.

14) Scott RL, Austic RE. Influence of dietary potassium on lysine metabolism in the chick. J. Nutr., 108 : 137-144. 1978.

15) Sekine $T, W$ atanabe $E$, Ishibashi $T$. Influence of dietary amino acids and calcium-available 
phosphorus on bone development of female broiler chicks. Anim. Sci. Technol. (Jpn.), 65 : 999-1007. 1994.

16) Shafey TM, McDonald MW, Pym RAE. Effects of dietary calcium, available phosphorus and vitamin $\mathrm{D}$ on growth rate, food utilisation, plasma and bone constituents and calcium and phosphorus retention of commercial broiler strains. Br. Poult. Sci., 31 : 587-602. 1990.

17) Ueno $K$, Koide $K$, Ishibashi $T$. Factors affecting arginine requirement in broilers. Anim. Sci. Technol. (Jpn.), $65: 9-15.1994$.

18) Wang SH, Nesheim MC. Degradation of lysine in chicks. J. Nutr., $102: 583-596.1972$.

19) Weiss RE, Gorn A, Dux S, Nimni ME. Influence of high protein diets on cartilage and bone formation in rats. J. Nutr., $111: 804-816.1981$.

20) Zemel MB. Calcium utilization : Effect of varying level and source of dietary protein. Am. J. Clin. Nutr., $48: 880-883.1988$.

\title{
ブロイラーの骨成長に対する飼料中のリジンおよび アルギニン含量の影響
}

\author{
関根時江 ·上野啓介・渡辺恵美子*・門脇基二 ・石橋 晃 \\ 新潟大学農学部, 新潟市 950-21 \\ *東京テクニカルカレッジバイオテクノロジー科, 国立市 186
}

\begin{abstract}
ブロイラーの脚弱を栄養学的に改善するため,ブロイラーの骨成長に及ぼす飼料中のリジンおよびア ルギニン含量の影響を検討した８日齢のコブ系雌ブロイラーヒナを単飼し，10日間試験飼料および水 を自由摄取させた，試験飼料はリジンの影響を明確にするため，アルギニンを $0.8 \%$ と一定にした飼料 に，リジンを $0.6 ， 1.0 １ .4 ， 1.8$ および $2.2 \%$ となるように添加し，リジン/アルギニン比の異なる 5 飼料 を作成した。 また，高りジンではあるがリジン/アルギニン比を低くするために，リジンが $2.2 \%$ でアル

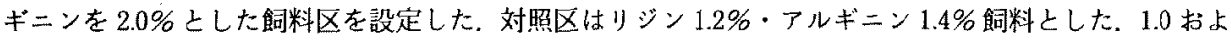
び 1.4\%リシン飼料区の体成長お上び骨成長は，対照区と有意な差は認められなかった，しかし，0.6\% の低リジン飼料区扔よび 1.8 と $2.2 \%$ の高リジン飼料区では，対照区に比べ有意に少った. 1.8 および $2.2 \%$ の高リジン飼料区に扔いて，脚弱七ナが多発したが，0.6\%の低リジン飼料区では脚弱七ナは観察 されなかった．また，2.2\%リジン飼料でアルギニンを $2.0 \%$ に增加させることにより，リシン過剩の影 響が緩和されることが示された。飼料中のリジン/アルギニン比の高い区では，血中の $\mathrm{pH}$ が他の区より 当低加った。

こ机らの結果から，飼料中のリジン/アルギニン比が高くなると体成長および骨成長が抑制され，脚弱 が発生したが，それには血中の $\mathrm{pH}$ の低下が関与していることが示唆された.
\end{abstract}

日畜会報, $67(1) ： 7-13,1996$ 